\title{
TESTING ACCESSION GENETIC COMPOSITION OF A GERM-PLASM BANK FOR MANGABEIRA (Hancornia speciosa)
}

\author{
VALIDAÇÃO DA AMOSTRAGEM PARA COMPOSIÇÃO DE UM BANCO DE \\ GERMOPLASMA DE MANGABEIRA (Hancornia speciosa)
}

\author{
Ronaldo Rodrigues COIMBRA ${ }^{1}$; Danielle Pereira dos SANTOS ${ }^{2}$; \\ Wagner de Melo FERREIRA ${ }^{3}$; Waldesse Piragé de OLIVEIRA JUNIOR ${ }^{4}$; \\ Elainy Cristina Alves Martins OLIVEIRA ${ }^{5}$
}

1. Curso de Ciências Biológicas, Universidade Federal do Tocantins - UFT, Porto Nacional, TO, Brasil; 2. . Mestre em Ecologia de Ecótonos, UFT, Porto Nacional, TO, Brasil; 3. Curso de Ciências Biológicas, UFT, Porto Nacional, TO, Brasil; 4. Curso de Engenharia Ambiental, UFT. Campus de Palmas. Palmas, TO, Brasil; 5. Curso de Engenharia de Bioprocessos e Biotecnologia, UFT, Gurupi, TO,

Brasil.biocristina@hotmail.com

\begin{abstract}
The objective of the current study was to measure the genetic variability of natural populations of Hancornia speciosa using RAPD type molecular markers to assay variation in existing sampled genotypes, using morphological variables, and so assess germplasm bank composition. Morphological and chemical characteristics $H$. speciosa fruits and seeds were evaluated using descriptive statistics and principal components analysis. Cluster analyzes was conducted using Jaccard's similarity index, via the UPGMA hierarchical agglomerative method. Phenotypic variability was found in the two studied populations. However, variability was higher in the São Judas population, where the variables: pulp yield and soluble solids content were higher than those in the Canaã population. High genetic variability was found in both study populations, and between- and within-population morphological and genetic variation was present in the studied populations. The nine primers generated 70 bands, of which 68 were polymorphic, with the primers A-08 and $\mathrm{C}-04$ generating the highest number of polymorphic bands. The two populations differ principally in the pulp ratio and the proportion of total solids in the pulp ( ${ }^{\circ}$ Brix). RAPD markers used gave acceptable results and, to initiate the Federal University of Tocantins Active Mangaba Germplasm Bank, seven genotypes were sampled from the Canaã population and five from the São Judas Tadeu population.
\end{abstract}

KEYWORDS: Genetic resources. Genetic variability. Hancornia speciose. Mangaba.

\section{INTRODUCTION}

The Cerrado is being drastically modified by anthropic activities, mainly for agricultural and human population expansion. It is estimated that $55 \%$ of the area of this biome has been deforested or transformed, which corresponds to three times the area deforested in Amazonia (SANO et al., 2007). Overall, only $2.2 \%$ of the entire Cerrado area is under legal protection and, of the endangered species of animals and plants that inhabit this biome, $20 \%$ are endemic but do not occur in the designated protected areas (KLINK; MACHADO, 2005).

Among the species at risk is mangabeira (Hancornia speciosa Gomes: Apocynaceae), which is notable among native Brazilian fruit trees for having received great interest from agroindustry. The fruit is highly nutritious, rich in provitamin A, vitamins $\mathrm{B} 1, \mathrm{~B} 2$ and $\mathrm{C}$, as well as iron, phosphorus and zinc (FREITAS, 2012b). In addition, the fruits are aromatic, and tasty, with wide market acceptance, both for household consumption and for agroindustry (MUNIZ et al., 2013). Among the native fruits of northeast Brazil, mangaba produces one of the most important raw materials for industrial fruit juice and ice cream production (DA SILVA JÚNIOR et al., 2018).

Studies on the genetic diversity of the remaining wild mangabeira populations are essential to establish effective strategies for the conservation of the species, especially in view of the increasing loss of habitat within its natural range. One option is to set up Active Germplasm Banks (AGBs). Evaluation of genetic diversity among AGB accessions provides information on potential parent plants that can be used in breeding programs; facilitates the identification of duplicates and exchange of germplasm between researchers; and provides a means of reconciling agrobiodiversity conservation efforts with sustainable development (COSTA et al., 2011; NASS, 2007). Germplasm banks allow conservation of the genetic diversity of populations threatened with extinction, providing study material with which methods for conservation 
of populations and endangered species can be investigated.

With the advent of modern molecular biology techniques, a variety of methods have emerged for detecting genetic polymorphism. Studies using molecular characterization allow the degree of polymorphism between and within populations to be inferred (COSTA et al., 2011). Molecular markers such as the Random Amplification of Polymorphic DNA (RAPD) technique are widely used for studies of genetic diversity (FERREIRA; GRATTAPAGLIA, 1998), due to the speed and simplicity with which results are obtained, capacity to cover the entire genome of the individual under study, and the ease of implementation and lower cost compared to other markers (SADDER; ATEYYEH, 2006).

However, information on genetic variability in natural populations of Hancornia speciosa Gomes in the Cerrado region is currently scarce. Therefore, the current study had the objective of quantifying the genetic variability of natural Hancornia speciosa populations of using RAPD type molecular markers to assay genotypes accessions, collected using morphological variables, for suitability for inclusion in a germplasm bank.

\section{CONTENTS}

\section{Study area}

The study was conducted in 2013, with two natural populations of $H$. speciosa, present in fragments of Cerrado with a typical appearance: (i) the Canaã population is located on a rural property approximately $10 \mathrm{~km}$ from the urban centre of the municipality of Porto Nacional, Tocantins State, Brazil, located on the margin of the TO 230 highway connecting Porto Nacional to Monte do Carmo (1040'23,1'S and 48 20 '54,3' $\mathrm{W}$, altitude of $280 \mathrm{~m}$ ), and (ii) the São Judas Tadeu population, located on the São Judas Tadeu rural property, some $24 \mathrm{~km}$ from Porto Nacional, Tocantins State, on the side of the TO 070 highway linking Porto Nacional and Brejinho de Nazaré $\left(10^{\circ} 48^{\prime} 0,6^{\prime \prime} S\right.$ and $48^{\circ} 25^{\prime} 37,3^{\prime \prime} \mathrm{W}$, altitude of $260 \mathrm{~m}$ ).

The city of Porto Nacional lies at an altitude of $212 \mathrm{~m}$, and the regional climate has two seasons, a dry season between May and September and a rainy season between October and April. Mean annual temperature is $26.1^{\circ} \mathrm{C}$, and mean annual rainfall 1,667.9 mm (SOUZA; GOMES, 2012).

\section{Morphological characterization - background}

Morphological data obtained by Freitas (2012a) and Freitas (2012b) were used for studies carried out in Cerrado fragments that were chosen because they had an appearance representatively typical of the regional version of this biome. Field studies were conducted from September to November in 2008 (Canaã Population) and 2011 (São Judas Tadeu Population). In the Canaã population, 55 genotypes; associated with plant and fruit variation were sampled, and from the São Judas Tadeu population 22 genotypes associated with such variation were sampled.

\section{Obtaining morphological and genetic data to test samples for the Germplasm Bank}

Ten genotypes from each population were georeferenced with a GPS, each plant was adult, with mature fruit, and located at least 20 (twenty) meters away from other genotypes.

At each study site, 10 soil samples were collected, at depths of $0-20 \mathrm{~cm}$, for physical and chemical analyzes $(\mathrm{pH} \mathrm{CaCl} 2$ - $\mathrm{pH}$ from calcium chlorate; $\mathrm{Ca}$ - calcium; $\mathrm{Mg}$ - magnesium; $\mathrm{Al}$ aluminium; $\mathrm{H}+\mathrm{Al}$ - hydrogen+ aluminium; K potassium; P - phosphorous; S - sulphur; Mat. Org. organic material; $\mathrm{Zn}$ - zinc; $\mathrm{Cu}$ - copper; Fe - iron; Mn- manganese; CTC - cation exchange capacity; $\mathrm{V}$ - saturation of bases). Climate data for Porto Nacional municipality, over the study period, was obtained from the National Institute of Meteorology (INMET).

\section{Obtaining morphological data}

Fruit variables: Twenty fruits per genotype were sampled, and the following variables measured for each fruit: longitudinal diameter (LD, $\mathrm{mm}$ ) and transverse diameter of the fruit (TD, mm), using calipers; fruit mass (FM, g), seed mass (SM, g) and pulp mass (PM, g), obtained by gravimetry, with an analytical balance; number of seeds (NS,), counted manually; and pulp yield (PY,\%), obtained from the ratio between pulp mass and fruit mass.

Seed variables: two seeds per fruit were sampled from each genotype. Variables measured were: transverse diameter of seed (TDS, $\mathrm{mm}$ ) thickness $(\mathrm{T}, \mathrm{mm})$, longitudinal diameter of the seed (LDS, mm) using calipers, and seed mass (SM, unit, g), with an analytical balance

Chemical variables: To measure chemical variables, pulp from fruits from the same individual were combined and stored in a freezer at $-20^{\circ} \mathrm{C}$. Later, the ionic hydrogen potential $(\mathrm{pH})$ was measured with a glass membrane potentiometer, adjusted with buffers at $\mathrm{pH} 7$ and 4, by placing the electrode directly in a $5 \mathrm{~g}$ sub-sample of unfrozen 
pulp, filtered through gauze. Subsequently, a further $100 \mu 1$ of obtained pulp extract was pipetted into the prism of a portable refractometer, obtaining a direct reading of the total soluble solids contents ( $\left.{ }^{\circ} \mathrm{Brix}\right)$ at an ambient temperature of $20^{\circ} \mathrm{C}$.

\section{Obtaining molecular data}

Young leaves were obtained from the ten genotypes sampled in each population, placed in paper bags and stored on ice until arrival at the laboratory. Here they were frozen in a freezer at -20 ${ }^{\circ} \mathrm{C}$ until extraction.

For the extraction of total genomic DNA, we used the CTAB extraction method described by Murray and Thompsom (1980), with modifications as used by Moura et al. (2005) for extraction of mangaba DNA. DNA concentration of each sample was estimated by means of spectrophotometry and comparison with a sample of known concentration of $\lambda$ phage DNA in $0.8 \%$ agarose gel.

We used ten Random Amplified Polymorphic DNA primers developed by Operon Technologies, belonging to kits $\mathrm{A}, \mathrm{C}$ and $\mathrm{H}$, and identified by Moura et al. (2005) as polymorphic in mangaba plants. The primers were: A-08, A-09, C04, C-08, H-02, H-09, H-10, H-15, H-18 and H-19, all were oligonucleotides, with 10 bases of arbitrary sequence. DNA samples were then amplified, each amplification reaction consisting of $25 \mu \mathrm{l}$ that contained: $5 \mathrm{ng}$ DNA; $50 \mathrm{mM} \mathrm{KCl}, 10 \mathrm{mM}$ Tris$\mathrm{HCl} \mathrm{pH} \mathrm{8.3;} 1.75 \mathrm{mM} \mathrm{MgCl} ; 0.2 \mathrm{mM}$ dNTPs; $30 \mathrm{ng}$ of primers and 1.5 units of Taq polymerase. Samples were subjected to 48 cycles of amplification after initial denaturation at $92^{\circ} \mathrm{C}$ for four minutes. Each cycle consisted of one minute at $92^{\circ} \mathrm{C}$, one minute and 30 seconds at $37^{\circ} \mathrm{C}$, and one minute and 30 seconds at $72^{\circ} \mathrm{C}$. A final extension of 5 minutes at $72^{\circ} \mathrm{C}$ occurred at the end of the 48 cycles.

To check for polymorphisms, fragments generated by amplification were separated by $1.4 \%$ horizontal agarose gel electrophoresis at a concentration of $1 \%$ in TBE buffer $(90 \mathrm{mM}$ Trisborate and $2 \mathrm{mM}$ EDTA). Gels were stained with ethidium bromide, observed under UV light and photographed. When interpretating the gels, each individual was genotyped according to the presence or absence of bands for the analyzed primers, selecting only the clearest and most wellspaced bands, so generating a matrix of binary data comprised of band presence (1) or absence (0).

\section{Data analysis}

The physical-chemical analysis of soils from the areas of the native local populations were compared on the basis of the results of the by performing the Kruskal Wallis test, followed by a Dunn test set at $5 \%$ probability. The same procedure was used to compare morphological variables for fruits and seeds from the two populations. With the morphological data, descriptive statistics were also performed to characterize populations and quantify within- population phenotypic variability. The extent of phenotypic variability of individual plants in the two populations was analyzed with Principal Component Analysis (PCA), and a figure generated from the first three main components.

A similarity matrix (Sij) was constructed using binary data derived from the Jaccard method. The respective genetic distances were calculated by calculating the Jaccard index $(\mathrm{Dij}=1-\mathrm{Sij})$. Evaluation of variation between the two populations, was made via a dendrogram constructed using a UPGMA clustering criterion.

Data from the National Meteorology Institute (INMET) showed that, during the study period the minimum and maximum temperature between July and November 2013 in the municipality of Porto Nacional were $20.8^{\circ} \mathrm{C}$ and $38.0^{\circ} \mathrm{C}$, respectively, and average temperature of $28.5^{\circ}$ C. Average precipitation was around 608.00 $\mathrm{mm}$.

The soil of both areas where study populations occurred naturally were classified as sandy clay (Table 1), based on sample classifications using the texture triangle of Nascimento et al. (2003). Soils of the two areas were nutrient-poor, acidic and with high concentrations of aluminum. However, soil from the Canaã population area had higher cation exchange capacity (CTC), higher organic matter content, greater acidity and aluminum content, as well as higher concentrations of potassium, zinc and copper when compared those from the São Judas Tadeu population area (Table 1). In contrast, soil from the São Judas Tadeu area had higher concentrations of iron, manganese and greater base saturation. 
Table 1. Granulometric and chemical analysis of soils from the two study areas (Canaã and São Judas Tadeu populations), Porto Nacional, Tocantins State, Brazil.

\begin{tabular}{lcc}
\hline Components & \multicolumn{1}{c}{ Populations } & \\
& Canaã & São Judas Tadeu \\
\hline Granulometric analysis & & \\
\hline Clay $(\%)$ & $32.00 \mathrm{a}$ & $16.70 \mathrm{~b}$ \\
Silt $(\%)$ & $16.00 \mathrm{a}$ & $10.80 \mathrm{~b}$ \\
Sand $(\%)$ & $52.00 \mathrm{~b}$ & $72.50 \mathrm{a}$ \\
\hline Chemical analysis & & \\
\hline $\mathrm{pH}(\mathrm{CaCl} 2)$ & $3.94 \mathrm{~b}$ & $4.14 \mathrm{a}$ \\
$\mathrm{Ca}(\mathrm{meq} / 100 \mathrm{ml})$ & $0.18 \mathrm{a}$ & $0.23 \mathrm{a}$ \\
$\mathrm{Mg}(\mathrm{meq} / 100 \mathrm{ml})$ & $0.14 \mathrm{a}$ & $0.15 \mathrm{a}$ \\
$\mathrm{Al}(\mathrm{meq} / 100 \mathrm{ml})$ & $1.05 \mathrm{a}$ & $0.54 \mathrm{~b}$ \\
$\mathrm{H}+\mathrm{Al}(\mathrm{meq} / 100 \mathrm{ml})$ & $12.21 \mathrm{a}$ & $4.40 \mathrm{~b}$ \\
$\mathrm{~K}(\mathrm{meq} / 100 \mathrm{ml})$ & $0.15 \mathrm{a}$ & $0.10 \mathrm{~b}$ \\
$\mathrm{P}(\mathrm{mg} / \mathrm{dm} 3)$ & $2.49 \mathrm{a}$ & $2.69 \mathrm{a}$ \\
$\mathrm{S}(\mathrm{mg} / \mathrm{dm} 3)$ & $1.78 \mathrm{a}$ & $1.99 \mathrm{a}$ \\
$\mathrm{Mat}$ Org. $(\%)$ & $2.13 \mathrm{a}$ & $0.65 \mathrm{~b}$ \\
$\mathrm{Zn}(\mathrm{mg} / \mathrm{dm} 3)$ & $0.39 \mathrm{a}$ & $0.12 \mathrm{~b}$ \\
$\mathrm{Cu}(\mathrm{mg} / \mathrm{dm} 3)$ & $0.59 \mathrm{a}$ & $0.36 \mathrm{~b}$ \\
$\mathrm{Fe}(\mathrm{mg} / \mathrm{dm} 3)$ & $46.70 \mathrm{~b}$ & $80.60 \mathrm{a}$ \\
$\mathrm{Mn}(\mathrm{mg} / \mathrm{dm} 3)$ & $3.70 \mathrm{~b}$ & $32.40 \mathrm{a}$ \\
\hline $\mathrm{CTC}$ & $12.68 \mathrm{a}$ & $4.87 \mathrm{~b}$ \\
\hline V (\%) & $3.75 \mathrm{~b}$ & $9.76 \mathrm{a}$ \\
\hline
\end{tabular}

$\mathrm{pH} \mathrm{CaCl}$ - $\mathrm{pH}$ from calcium chlorate; $\mathrm{Ca}$ - calcium; $\mathrm{Mg}$ - magnesium; $\mathrm{Al}$ - aluminium; $\mathrm{H}+\mathrm{Al}$ - hydrogen+ aluminium; $\mathrm{K}$ - potassium; $\mathrm{P}$ - phosphorous; S - sulphur; Mat. Org. - organic material; $\mathrm{Zn}$ - zinc; $\mathrm{Cu}$ - copper; Fe - iron; Mn- manganese; CTC - cation exchange capacity; V - saturation of bases.*Values on the same line followed by the same letter did not differ when tested with Kruskal-Wallis, followed by a Dunn Test at $5 \%$ probability.

According to Ferreira and Marinho (2007), $H$. speciosa is tolerant of low soil fertility, and develops well in those with low organic matter content and low nutrient availability. The plant is also drought tolerant, a result of an extensive root system that invests a large volume of soil, absorbing water and nutrients deep within the soil profile.

Within each population between-plant variation was greatest for the variables seed mass, seed number, fruit mass and pulp mass (Table 2).

Table 2. Range, mean, standard deviation and coefficient of variation for fruit characteristics from 55 genotypes from two natural mangabeira populations. Porto Nacional, Tocantins State, Brazil.

\begin{tabular}{|c|c|c|c|c|c|c|c|c|c|c|c|c|}
\hline Genotypes & $\begin{array}{l}\text { FLD } \\
(\mathrm{mm})\end{array}$ & $\begin{array}{l}\text { FTD } \\
(\mathrm{mm})\end{array}$ & $\begin{array}{c}\text { FM } \\
(\mathrm{g})\end{array}$ & $\begin{array}{c}\text { SM } \\
(\mathrm{g})\end{array}$ & $\begin{array}{c}\text { PM } \\
(\mathrm{g})\end{array}$ & $\begin{array}{l}\text { SN } \\
\text { (und.) }\end{array}$ & $\begin{array}{l}\text { STD } \\
(\mathrm{mm})\end{array}$ & $\begin{array}{l}\text { SLD } \\
(\mathrm{mm})\end{array}$ & $\begin{array}{c}\text { ST } \\
(\mathrm{mm})\end{array}$ & $\begin{array}{l}\text { PR } \\
(\%)\end{array}$ & ${ }^{\circ} \mathrm{BRIX}$ & $\mathrm{pH}$ \\
\hline \multicolumn{13}{|c|}{ Population Canaã } \\
\hline 1 & 32.30 & 33.31 & 23.01 & 3.85 & 17.91 & 8.70 & 9.54 & 11.98 & 3.34 & 79.11 & 15.50 & 3.62 \\
\hline 2 & 32.90 & 33.95 & 22.83 & 4.74 & 17.11 & 14.30 & 9.05 & 11.08 & 3.03 & 75.30 & 13.00 & 3.74 \\
\hline 3 & 33.97 & 24.98 & 11.54 & 2.20 & 8.78 & 6.20 & 8.91 & 11.19 & 3.53 & 76.01 & 11.00 & 3.45 \\
\hline 4 & 39.84 & 35.13 & 32.21 & 4.43 & 26.85 & 9.70 & 9.46 & 12.78 & 3.30 & 84.03 & 15.00 & 3.15 \\
\hline 5 & 36.22 & 35.47 & 27.89 & 8.21 & 18.61 & 19.10 & 9.61 & 11.71 & 3.13 & 67.30 & 13.00 & 3.68 \\
\hline 6 & 34.79 & 33.33 & 25.55 & 5.10 & 19.22 & 16.30 & 8.58 & 10.39 & 3.34 & 75.63 & 13.00 & 3.47 \\
\hline 7 & 35.73 & 36.05 & 27.19 & 7.12 & 18.68 & 18.30 & 8.97 & 12.01 & 3.52 & 68.99 & 12.00 & 3.74 \\
\hline 8 & 36.02 & 36.72 & 29.41 & 2.41 & 25.81 & 7.40 & 8.64 & 10.89 & 2.85 & 87.58 & 15.00 & 3.48 \\
\hline 9 & 36.57 & 37.30 & 33.03 & 6.60 & 25.01 & 19.20 & 8.63 & 11.06 & 3.53 & 75.61 & 15.50 & 3.76 \\
\hline 10 & 33.97 & 32.81 & 22.10 & 5.84 & 14.72 & 16.90 & 8.46 & 10.93 & 3.30 & 67.44 & 16.00 & 3.23 \\
\hline Mini & 32.30 & 24.98 & 11.54 & 2.20 & 8.78 & 6.20 & 8.46 & 10.39 & 2.85 & 67.30 & 11.00 & 3.15 \\
\hline Max & 39.84 & 37.30 & 33.03 & 8.21 & 26.85 & 19.20 & 9.61 & 12.78 & 3.53 & 87.58 & 16.00 & 3.76 \\
\hline Mean & $35.2 \mathrm{a}$ & $33.9 \mathrm{a}$ & $25.5 \mathrm{a}$ & $5.0 \mathrm{a}$ & $19.3 \mathrm{a}$ & $13.6 \mathrm{a}$ & $9.0 \mathrm{a}$ & $11.4 \mathrm{~b}$ & $3.3 \mathrm{a}$ & $75.7 \mathrm{~b}$ & $13.9 \mathrm{~b}$ & $3.5 \mathrm{a}$ \\
\hline CV (\%) & 6.15 & 10.3 & 24.3 & 38.7 & 28.5 & 37.5 & 4.7 & 6.2 & 6.9 & 8.9 & 12.3 & 6.1 \\
\hline
\end{tabular}




\begin{tabular}{ccccccccccccc}
\multicolumn{2}{c}{ Population São Judas Tadeu } \\
1 & 37.38 & 39.34 & 37.50 & 3.44 & 32.87 & 8.00 & 8.76 & 11.26 & 3.24 & 88.16 & 16.00 & 3.07 \\
2 & 32.74 & 34.70 & 27.85 & 3.03 & 23.57 & 11.10 & 7.38 & 9.86 & 2.90 & 85.39 & 18.70 & 3.16 \\
3 & 35.62 & 31.95 & 24.80 & 3.15 & 19.66 & 7.10 & 8.47 & 11.23 & 3.31 & 80.69 & 15.50 & 3.51 \\
4 & 34.91 & 34.36 & 27.00 & 3.84 & 22.05 & 12.80 & 8.37 & 10.34 & 2.70 & 82.18 & 16.00 & 3.26 \\
5 & 41.32 & 39.76 & 41.55 & 7.15 & 31.75 & 16.40 & 8.79 & 12.04 & 3.21 & 77.18 & 16.00 & 3.32 \\
6 & 33.17 & 33.88 & 24.18 & 2.19 & 20.67 & 7.70 & 8.31 & 10.39 & 3.00 & 86.12 & 16.50 & 3.40 \\
7 & 27.53 & 28.21 & 15.30 & 1.47 & 12.55 & 5.00 & 8.17 & 10.21 & 2.74 & 82.07 & 18.00 & 3.18 \\
8 & 35.99 & 32.48 & 23.96 & 2.34 & 20.26 & 6.90 & 8.25 & 10.52 & 3.35 & 84.58 & 17.00 & 3.30 \\
9 & 42.25 & 41.03 & 45.49 & 6.76 & 36.73 & 17.60 & 8.38 & 10.51 & 3.42 & 81.02 & 19.00 & 3.77 \\
10 & 38.88 & 38.00 & 37.13 & 5.79 & 28.18 & 16.10 & 9.40 & 10.58 & 3.25 & 75.60 & 19.00 & 3.40 \\
Mini & 27.53 & 28.21 & 15.30 & 1.47 & 12.55 & 5.00 & 7.38 & 9.86 & 2.70 & 75.60 & 15.50 & 3.07 \\
Max & 42.25 & 41.03 & 45.49 & 7.15 & 36.73 & 17.60 & 9.40 & 12.04 & 3.42 & 88.16 & 19.00 & 3.77 \\
Mean & $36.9 \mathrm{a}$ & $35.4 \mathrm{a}$ & $30.5 \mathrm{a}$ & $3.9 \mathrm{a}$ & $24.8 \mathrm{a}$ & $10.9 \mathrm{a}$ & $8.4 \mathrm{a}$ & $10.7 \mathrm{a}$ & $3.1 \mathrm{a}$ & $82.3 \mathrm{a}$ & $17.2 \mathrm{a}$ & $3.3 \mathrm{a}$ \\
CV (\%) & 12.1 & 11.5 & 31.0 & 50.5 & 29.7 & 42.2 & 6.1 & 5.9 & 8.3 & 4.8 & 8.0 & 6.0 \\
\hline
\end{tabular}

FLD - fruit longitudinal diameter, FTD - fruit transverse diameter, FM - fruit mass, SM - seed mass, PM - pulp mass, SN - seed number, STD- seed transverse diameter, DLS - seed longitudinal diameter, ST - seed thickness, PR - pulp ratio. * Values followed by the same letter in the same column did not differ by Kruskal-Wallis, following a Dunn Test a 5\% probability. CV: coefficient of variation. Mini: Minimum.

The studied populations differed significantly in pulp yield $(\mathrm{p}=0.02)$ and total soluble solids content $\left({ }^{\circ}\right.$ Brix, $\left.\mathrm{p}=0.0004\right)$ in the Canaã population (Table 2).

Mean fruit mass for the Canaã population was $25.5 \mathrm{~g}$, and $30.5 \mathrm{~g}$ for São Judas Tadeu. Average-mangabeira fruit mass, reported by Gonçalves et al. (2013), was 23.01 g. Mean seed mass in the Canaã population was $5.0 \mathrm{~g}$, and $3.9 \mathrm{~g}$ at São Judas. Gonçalves et al. (2013) reported an average seed mass of $6.33 \mathrm{~g}$. According to Santos et al. (2009) variations in fruit weight may be due to genetic variability or variations caused by the environmental characteristics at different geographic locations.

For the Canaã population mean pulp mass was $19.3 \mathrm{~g}$, and $24.8 \mathrm{~g}$ in the São Judas Tadeu population. Ganga et al. (2010) reported a mean of $12.28 \mathrm{~g}$ for this variable, much lower than the values reported here. Pulp mass is one of the most important physical attributes for economic exploitation, especially for fruit processing (NASCIMENTO et al., 2014). Genotype 4 from the Canaã population and genotype 19 from São Judas Tadeu had notably high values for this character.

Average seed numbers per fruit were 13.6 for the Canaã population and 10.9 for São Judas Tadeu. Variation in seed number has considerable ecological importance, since high seed productivity can be a positive factor for individual reproduction (VIEIRA NETO, 2002; GONÇALVES et al., 2013) and facilitate species propagation. However, studies also show a tendency for fruits with higher number of seeds to have a lower pulp yield (FREITAS et al., 2012b).
Average pulp ratio was $75.7 \%$ for the Canaã population, and $82.3 \%$ for São Judas Tadeu. According to Chitarra and Chitarra (2005), pulp ratio is a very important quality-assessment parameter for agro-industry, when considering concentrates, purees, mass-produced sweets, fruit juices, etc. Fruits with a ratio yield above $50 \%$ are considered suitable for commercialization (LIMA et al., 2002).

Total soluble solids content is one of the most important characteristic of any commercializable fruit, because it is responsible for the taste of the pulp. The Canaã population had an average of 13.9 per fruit, while the value for São Judas Tadeu was 17.2. Santos et al. (2012), in a study carried out with mangaba in the wild, found a mean total soluble solids content of 14.83 , a result higher than that recorded for the Canaã population, but lower than that from São Judas Tadeu. It may be noted that, while the soil at Canaã is slightly more fertile than that at São Judas, this was not reflected in larger fruits with higher pulp yields and Brix values. This maybe because the species is not very demanding of nutrients, developing well in low fertility soils (FERREIRA; MARINHO, 2007).

For the PCA, the first three components explained $82.2 \%$ of the total variation. Figure 2 allows a simultaneous graphic appreciation of the extent of phenotypic variability present in the two sample populations, and shows the presence of two distinct clusters, one formed by Canaã population samples and the other by those from São Judas Tadeu. 


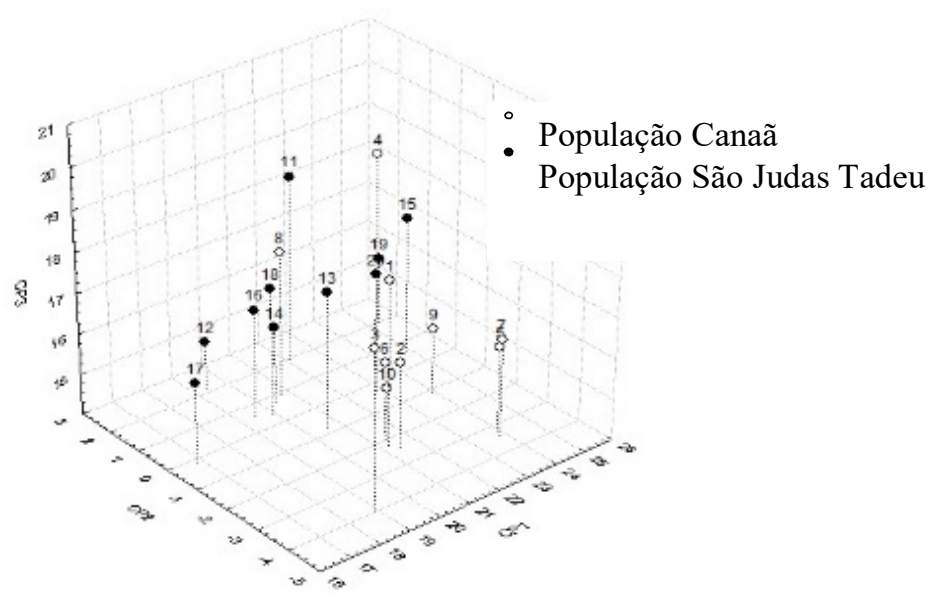

Figura 2. Scatter plot generated from the scores of the first three principle components, based on morphological characteristics of sampled individuals from the Canaã and São Judas Tadeu populations. Here, genotypes from 1 to 10 are from the Canaã population, while 11 to 20 are from the São Judas Tadeu population.

In the first principle component, the variables contributing most to between-genotype discrimination were seed mass, fruit longitudinal diameter, fruit transversal diameter and fruit mass, in the second component being Brix, pulp ratio and pulp mass and the third component being transverse and longitudinal diameter of seeds.

Figure 2 also shows the greater phenotypic variability present in the São Judas Tadeu population, than in the Canaã population. Even so, there was considerable morphological similarity between individuals 19 and 20 of the São Judas Tadeu population, including longitudinal seed diameter (10.51 mm and $10.58 \mathrm{~mm}$ ), seed thickness (3.42 $\mathrm{mm}$ and $3.25 \mathrm{~mm}$ ), Brix (19.00 and 19.00) and pulp pH (3.77 and 3.40). These two individuals also showed the highest Brix values in the São Judas Tadeu population sample. In this population, individuals 14, 16 and 18 were also very similar, all showing values close to the population mean for such variables as pulp mass, transverse and longitudinal seed diameter, $\mathrm{Brix}^{\circ}$, and fruit $\mathrm{pH}$. The Canaã population showed two similarity subgroups, one composed individuals 2, 3, 6 and 10 - all of which had values close to the population mean for transverse and longitudinal seed diameter, seed thickness and $\mathrm{pH}-$ and a second group, composed of genotypes 5 and 7 , that were very similar to each other for all studied variables.

While individuals 1, 4 and 8 from the Canaã population were divergent compared to the rest of the population, they showed a great similarity to the general São Judas population phenotype. The morphological study found greatest overall phenotypic variability in the São Judas Tadeu population. According to Ganga et al. (2010), the extensive level of phenotypic variation found in Hancornia speciosa is of great importance in the development of effective conservation strategies, as well as for the domestication and cultivation of the species.

For molecular data analysis, of the ten primers tested, nine showed amplification. Of these, all had at least four polymorphic bands (Figure 3). Overall, the number ranged from four to fifteen bands per primer, with a mean of 7.9 bands. 


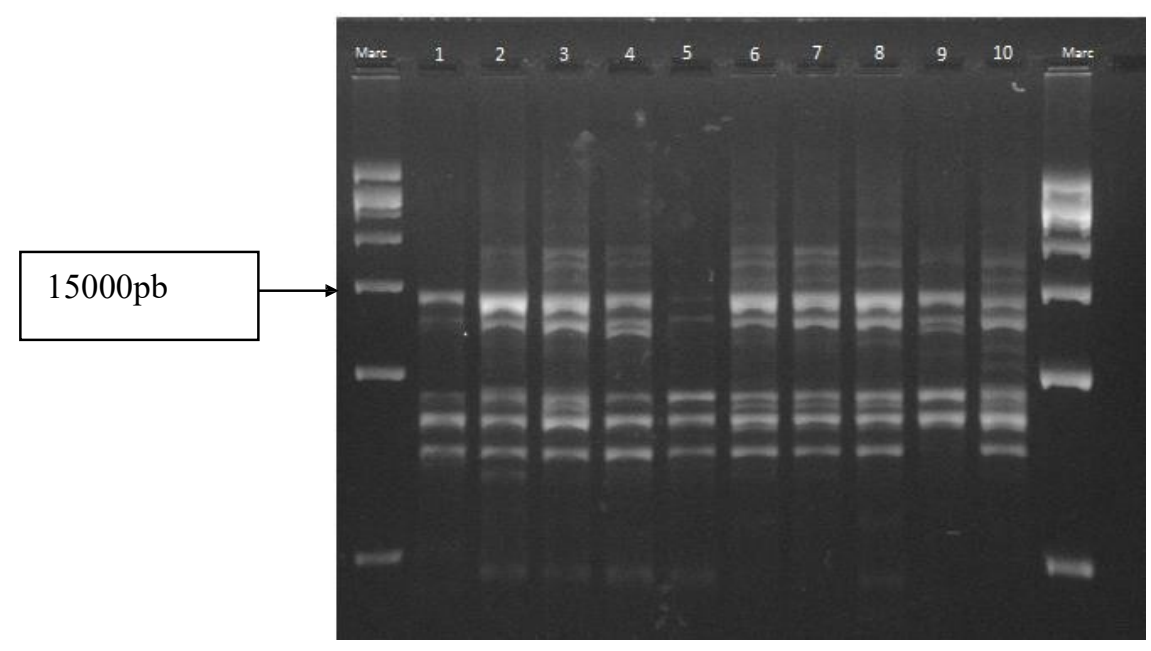

Figure 3. An example of a RAPD gel, this one using the Operon H-15 primer on 10 genotypes from the Canaã population.

The most polymorphic primers were C-04 and A-08, with 15 and 12 bands, respectively. In total 70 bands were generated by the nine primers, with fragments ranging from 750 to $3000 \mathrm{bp}$ (Table
3). Of these, only two bands were monomorphic, so that the degree of polymorphism was $88.23 \%$, indicating that there is considerable genetic variability within the studied populations.

Table 3. Primer base sequences, total number of bands (TNB), number of polymorphic bands (NPB) and percentage of polymorphism for each primer.

\begin{tabular}{ccccc} 
Primer & Sequence 5 $\mathbf{- 3}^{\mathbf{c}}$ & TNB & NPB & $\begin{array}{c}\text { Polymorphism } \\
\mathbf{( \% )}\end{array}$ \\
\hline A-08 & TCGGACGTGA & 12 & 11 & 91.67 \\
A-09 & GGGTAACGCC & 8 & 8 & 100,0 \\
C-04 & CCGCATCTAG & 15 & 15 & 100.0 \\
C-08 & TGGACCGGTG & 8 & 8 & 100.0 \\
H-02 & GTGACGTAGG & 7 & 7 & 100.0 \\
H-09 & TGTAGCTGGG & 3 & 3 & 100.0 \\
H-15 & AATGGCGCAG & 5 & 4 & 80.0 \\
H-18 & GAATCGGCCA & 4 & 4 & 100.0 \\
H-19 & CTGACCAGCC & 8 & 8 & 100.0 \\
\hline Mean & & 7.78 & 7.56 & 96.85 \\
\hline Total & & 70 & 68 & \\
\hline
\end{tabular}

Polymorphism levels were $83 \%$ in the São Judas Tadeu, and 76\% for Canaã population. Given the results of UPGMA genotype grouping, and the Jaccard Index (Figure 4) as an index of dissimilarity, there is great variability both within and between the populations, especially when the small size of the current sample is considered. 


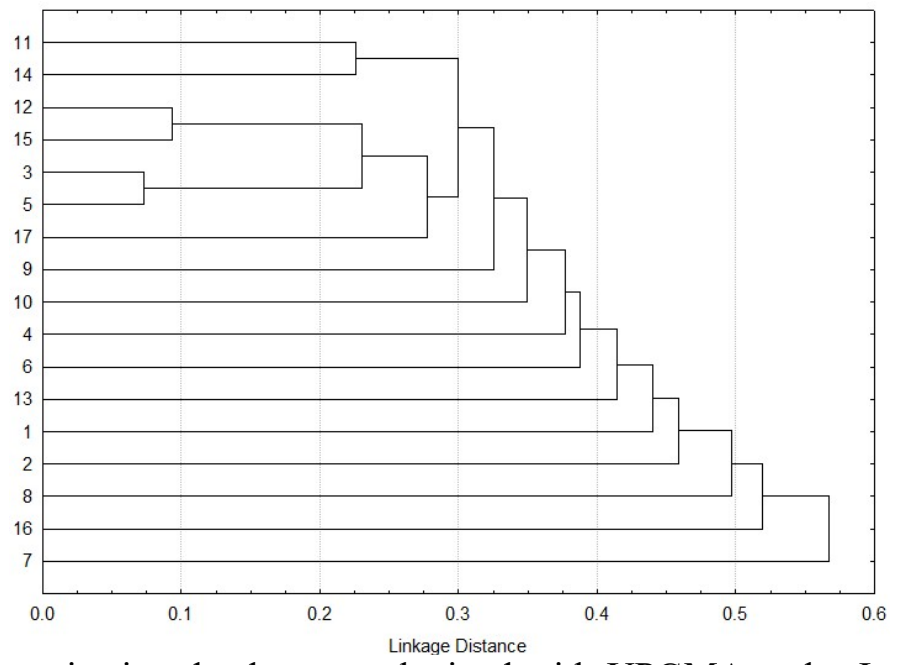

Figure 4. Molecular characterization dendrogram obtained with UPGMA and a Jaccard Index coefficient for 17 mangabeira genotypes from two natural populations in Porto Nacional, Tocantins, Brazil

In general, individual samples differed widely from each other and did not cluster. However, there is similarity between populations for this group of primers, since genotypes 13 and 16 from the São Judas Tadeu population are genetically closer to Canaan population genotypes. The same is true for genotypes 3 and 5 of the Canaã population, which are both very similar to each other and genetically closer to genotypes from São Judas Tadeu than others in the Canaã sample.

It is noticeable that the RAPD markers used effectively assayed genetic diversity of the studied mangabeira populations. Of the 17 genotypes sampled, only four show even moderate genetic similarity ( 3 and 5, 12 and 15).

The populations are genetically distinct, but the Canaã population showed greater genetic variability. This is in contrast to morphological analysis, where the São Judas Tadeu population was found to be more variable.

As a result of morphological and molecular analyzes, genotypes 1, 8, 4 and 9 from the Canaã population will be accessed into the germplasm bank as they are morphologically and genetically divergent, while genotype 5 and genotypes 6 and 10 will be accessed because of their high pulp yields and ${ }^{\circ}$ Brix, and large fruit sizes in comparison to other samples from the sample population.

In the São Judas population, individuals 11 and 15 were morphologically divergent, and showed some degree of genetic similarity. Samples from these individuals have a similar ${ }^{\circ}$ Brix, but 11 had the highest pulp ratio and therefore, will also be accessed into the collection. Genotypes 12 and 17 are very similar morphologically and genetically, but genotype 12 has greater fruit size, and higher pulp ratio and ${ }^{\circ}$ Brix values, and will therefore be assessed into the collection. Individuals 14, 16 and 18 are similar morphologically, with below-average scores for many variables. Accordingly, only genotype 16 will be accessed, since it has the highest pulp ratio in this subgroup. Genotype 13 will not be sampled because it has below-average scores for nearly all variables, and also because it is genetically similar to already-sampled Canaã population genotypes. DNA analysis of the genotypes of individuals 18,19 and 20 was not possible because the samples did not amplify. However, the genotypes of 19 and 20 will be sampled because they have higher ${ }^{\circ}$ Brix and good pulp yields.

RESUMO: O presente trabalho teve como objetivo mensurar a variabilidade genética de populações naturais de Hancornia speciosa utilizando marcadores moleculares do tipo RAPD para validar a amostragem de genótipos, realizada por meio de variáveis morfológicas, para a composição de um banco de germoplasma. Foram avaliadas características morfológicas e químicas de frutos e sementes de mangaba, utilizando-se estatística descritiva e análise de componentes principais. As análises de agrupamento foram feitas utilizando índice de similaridade de Jaccard, através do método hierárquico aglomerativo UPGMA. Foi observada grande variabilidade fenotípica nas duas populações estudas, porém, essa variabilidade foi maior na população São Judas, onde as variáveis: rendimento de polpa e teor de sólidos solúveis foram maiores que os encontrados na população Canaã. Observou-se uma elevada variabilidade genética nas duas populações estudadas e que existe 
variabilidade morfológica e genética entre e dentro das populações. As duas populações diferem principalmente em relação ao rendimento de polpa e teor de sólidos solúveis totais $\left({ }^{\circ}\right.$ Brix). Os nove iniciadores que amplificaram geraram 70 bandas, destas, 68 foram polimórficas, onde os primers A-08 e C-04 foram os que geraram maior número de bandas polimórficas. Portanto, os marcadores RAPD utilizados foram eficientes no presente estudo e para comporem o Banco Ativo de Germoplasma de Mangaba da Universidade Federal do Tocantins foram amostrados sete genótipos da população Canaã e cinco da população São Judas Tadeu.

PALAVRAS-CHAVE: Hancornia speciosa. Mangaba. Recursos Genéticos. Variabilidade Genética.

\section{REFERENCES}

CHITARRA, M. I. F.; CHITARRA, A. B. Pós-colheita de frutos e hortaliças: Fisiologia e manuseio. Lavras: ESAL/FAEPE. 320p. 2005.

COSTA, T. S.; SILVA, A. V. C.; LÉDO, A. S.; SANTOS, A. R. F.; SILVA JÚNIOR, J. F. Diversidade genética de acessos do Banco de Germoplasma de mangaba em Sergipe. Pesquisa Agropecuária Brasileira. Brasília v.46, n.5, p.499-508, 2011. https://doi.org/10.1590/S0100-204X2011000500007

DA SILVA JÚNIOR, J.F.; MUNIZ, A.V.C. DA S.; LÉDO, A. DA S.; MAIA, M.C.C.; CARVALHARES, M.A.; SILVA, S.M. DA C.; DULLOO, E.; ALERCIA, A. Descriptors for Mangaba (Hancornia speciosa Gomes). Bioversity International, Rome, Italy and Brazilian Agriculture Research Corporation. Embrapa Tabuleiros Costeiros, Aracaju, SE, Brazil. 2018.

FERREIRA, M.E.; GRATTAPAGLIA, D. Introdução ao uso de marcadores moleculares em análise genética. Brasília: EMBRAPA-CENARGEN. 220p. 1998.

FERREIRA, E.G; MARINHO, S.J.O. Produção de frutos de mangabeira para consumo in natura e industrialização. Tecnologia \& Ciência Agropecuária, v.1, p. 9-14, 2007.

FREITAS, M.K.C.; COIMBRA, R. R.; AGUIAR, G.B.; AGUIAR, C.B.N.; CHAGAS, D.B.; FERREIRA, W.M.; OLIVEIRA, R. J. Phenotypic variability and morphologic characterization of a natural population of Hancornia speciosa Gomes. Bioscience Journal. 28. 833-841. 2012a.

FREITAS, A. C. de. Mangaba (Hancornia speciosa Gomes): Localização de populações nativas no cerrado amapaense e caracterização morfológica das progênies do banco ativo de germoplasma. $72 \mathrm{f}$. Dissertação (Mestrado em Meio Ambiente, Cultura e Desenvolvimento Regional). Universidade Federal do Amapá, Macapá. 2012b.

GANGA, R. M. D.; FERREIRA, G. A.; CHAVES, L. J.; NAVES, R. V.; NASCIMENTO, J. L. DO. Caracterização de frutos e árvores de populações naturais de Hancornia speciosa Gomes do Cerrado. Revista Brasileira de Fruticultura. v.32, p.101-113. 2010. https://doi.org/10.1590/S0100-29452010005000019

GONÇALVES, L.G.V.; ANDRADE, F.R.; MARIMON JUNIO; SCHOSSLER, B.H.T.R.; LENZA, E.; e MARIMON, B.S. Biometria de frutos e sementes de mangaba (H. speciosa Gomes) em vegetação natural na região leste de Mato Grosso, Brasil. Revista de Ciências Agrárias. v. 36, n. 1, p. 31-40. 2013.

KLINK, C. A.; MACHADO, R. B. Conservation of the Brazilian Cerrado. Conservation Biology. v. 19, p. 707-13. 2005. https://doi.org/10.1111/j.1523-1739.2005.00702.x

LIMA, E. D. P. DE A.; LIMA, C. A. DE. A.; ALDRIGUE, M. L.; GONDIM, P. J. S. Caracterização física e química dos frutos da umbu-cajazeira (Spondias spp.) em cinco estádios de maturação da polpa congelada e néctar. Revista Brasileira de Fruticultura. v.24, p.338-343. 2002. https://doi.org/10.1590/S0100$\underline{29452002000200013}$ 
MOURA, N. F.; CHAVES, L. J.; VENCOVSKY, R.; ZUCCHI, M. I.; PINHEIRO, J.B.; MORAIS, L.K.; MOURA, M. F. Seleção de marcadores RAPD para o estudo da estrutura genética de populações de Hancornia speciosa GOMEZ. Bioscience Journal. v. 21, n.3, p.119-125. 2005.

MUNIZ, A. V. C. S.; YAGUIU, P.; MUNIZ, E. N.; VITÓRIA, M. F.; AMORIM, J. A. S. Vida útil de mangaba colhida em dois estádios de maturação. Aracaju: Embrapa Tabuleiros Costeiros. (Embrapa Tabuleiros Costeiros. Boletim de Pesquisa, 80). 15 p. 2013.

MURRAY, M.G.; THOMPSON, W.F. Rapid isolation of high molecular weight plant DNA. Nucleic Acids Reserch, Oxford. v. 8, n. 19, p. 4321-4325, Oct. 1980. https://doi.org/10.1093/nar/8.19.4321

NASS, L.L. Recursos genéticos vegetais. Brasília: Embrapa Recursos Genéticos e Biotecnologia. 858p. 2007.

NASCIMENTO, G.B.; PEREIRA, M.G.; ANJOS, L.H.C.; SOARES, E.D.R.; SOUZA, M.R.P.F. Determinação da classe textural de amostras de terra através de planilha eletrônica. Revista Universitária Rural. Série Ciências da Vida. Seropédica, RJ, EDUR, v. 23, n. 1, 2003. https://doi.org/10.1590/18071929/agriambi.v18n08p856-860

NASCIMENTO, R. S. M.; CARDOSO, J. A.; COCOZZA, F. D. M. Caracterização física e físico-química de frutos de mangabeira (Hancornia speciosa Gomes) no oeste da Bahia. Revista Brasileira de Engenharia Agrícola e Ambiental. 856-860. 2014.

SADDER, M. T.; ATEYYEH, A. F. Molecular assessment of polymorphism among local Jordanian access of commom fig (Ficus carica L.). Acta Horticulturae. The Hague, v.107, p.345-351. 2006.

https://doi.org/10.1016/j.scienta.2005.11.006

SANO, E. E.; ROSA, R.; BRITO, J. L. S.; FERREIRA, L. G. Mapeamento de cobertura vegetal do bioma Cerrado. Embrapa Cerrados. Planaltina. 2007.

SANTOS, F. S.; PAULA, R. C.; SABONARO, D. Z.; VALADARES, J. Biometria e qualidade fisiológica de sementes de diferentes matrizes de Tabebuia chrysotricha (Mart. ex A. DC.) Standl. Scientia Forestalis. v.37, p.163-173. 2009.

SANTOS, J.T.S.; COSTA, F.S.C.; SOARES, D.S.C.; CAMPOS, A.F.P.; CARNELOSSI, M.A.G.; NUNES, T.P.; JUNIOR, A.M.O. Avaliação de mangaba liofilizada através de parâmetros físico-químicos. Scientia Plena. Sergipe. v. 8, n. 3, p. 1-5. 2012.

SOUZA, L. B; GOMES, W. P. Mudanças microclimáticas em Porto Nacional (TO) e suas relações com o reservatório da UHE Luis Eduardo Magalhães: um estudo perceptivo com alunos do $3^{\circ}$ ano do ensino médio.

Revista Geonorte. Edição especial. v. 1, n. 5, p. 162-174. 2012.

VIEIRA NETO, R. D. Mangaba. In: VIEIRA NETO, R. D. Fruteiras potenciais para os Tabuleiros Costeiros e Baixada Litorânea. Aracaju: Embrapa- CPATC/Emdagro. p. 115 - 140. 2002. 